\title{
Ground Water and the Rural Homeowner
}
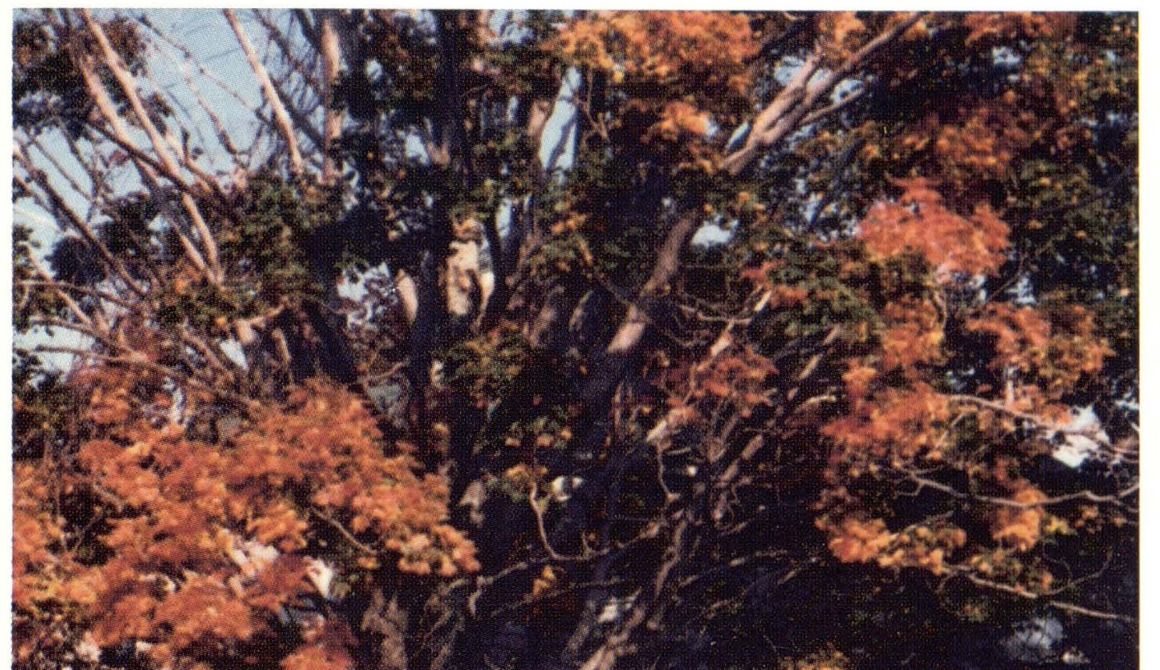

tore?

$y=\tan \left(x^{2}+x^{2}\right.$

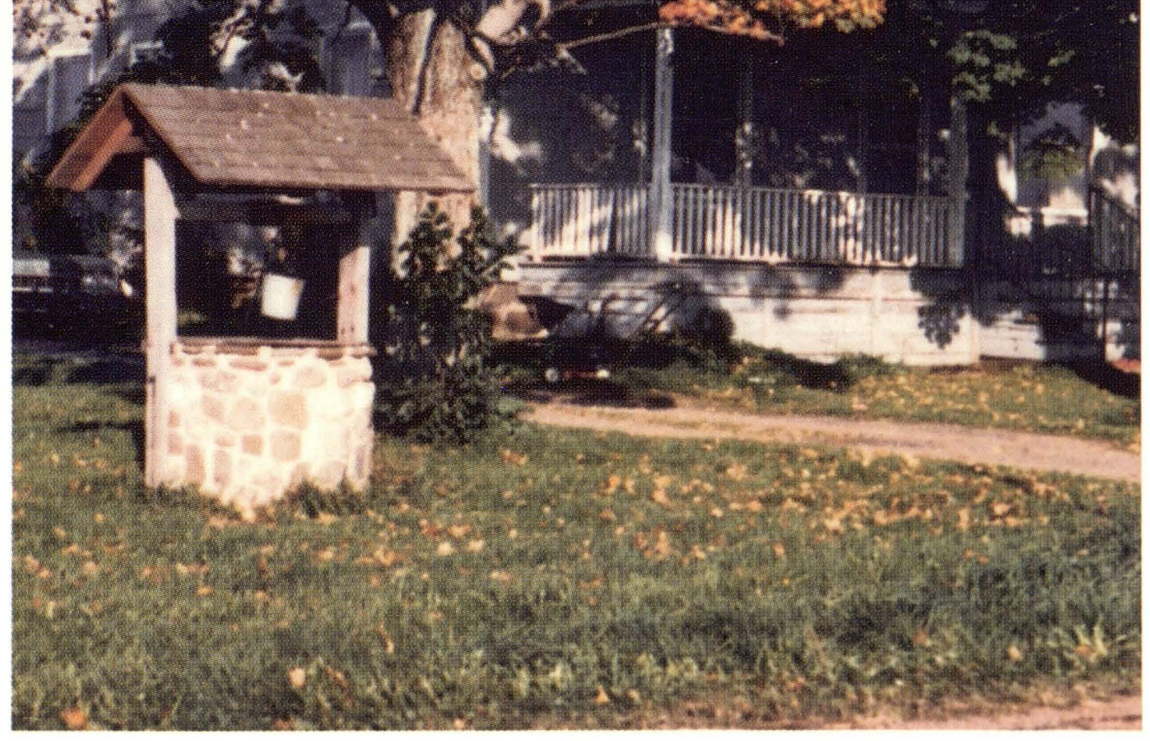


Cover photograph: Rural dug well. 


\section{Ground Water and the Rural Homeowner}

by Roger M. Waller 



\section{Preface}

As the salesmen sang in the musical The Music Man, "You gotta know the territory." This saying is also true when planning to buy or build a house. Learn as much as possible about the land, the water supply, and the septic system of the house before buying or building. Do not just look at the construction aspects or the beauty of the home and surroundings. Be sure to consider the environmental conditions around and beneath the site as well. Try to visit the site under adverse conditions, such as during heavy rain or meltwater runoff, to observe the drainage characteristics, particularly the condition of the basement.

Many of the conditions discussed in this book, such as lowered well-water levels, flooded basements, and contamination from septic systems, are so common that rural families often have to deal with one or more of them. The purpose of this book is to awaken an interest in ground water and an awareness of where it is available, how it moves, how people can adjust to its patterns to avoid problems, and how it can be protected and used wisely.

This booklet provides both present and prospective rural homeowners, particularly those in the glaciated northern parts of the United States, with a basic but comprehensive description of ground water. It also presents problems one may expect to encounter with ground water and some solutions or suggestions for help with these problems. 


\section{Introduction}

When buying a home in the country, people need to consider certain factors that usually do not confront the urban homebuyer, such as whether or not the water supply is adequate and if the means of disposing of wastewater is safe. Disappointed rural homeowners have sometimes found out too late that the well drilled on their new land does not yield enough water or that the water is of poor chemical quality. Also, foundations can become unstable from excess surface runoff or from high ground-water levels. Septic systems, if not located properly or if soil conditions are not properly considered, can fail. Wells can be contaminated by septic systems or barnyard wastes. Shallow or dug wells on farms or near older homes that served adequately in earlier years are often inadequate for modern uses.

Preventing water problems or coping with them when buying or building a rural home can be either complex or relatively simple. Prospective homeowners need to know about the terrain, the proximity of the house to other structures, and the condition of the existing well and septic system. If building in an unpopulated area, drill a well first-or if buying an old house, find out if the water supply is adequate. This booklet describes the most common well problems encountered by rural homeowners, how to recognize them, solve them, or get help. But first, the characteristics and behavior of ground water and the relationship between ground water and the surrounding land are discussed briefly. 


\section{The Hydrologic Cycle}

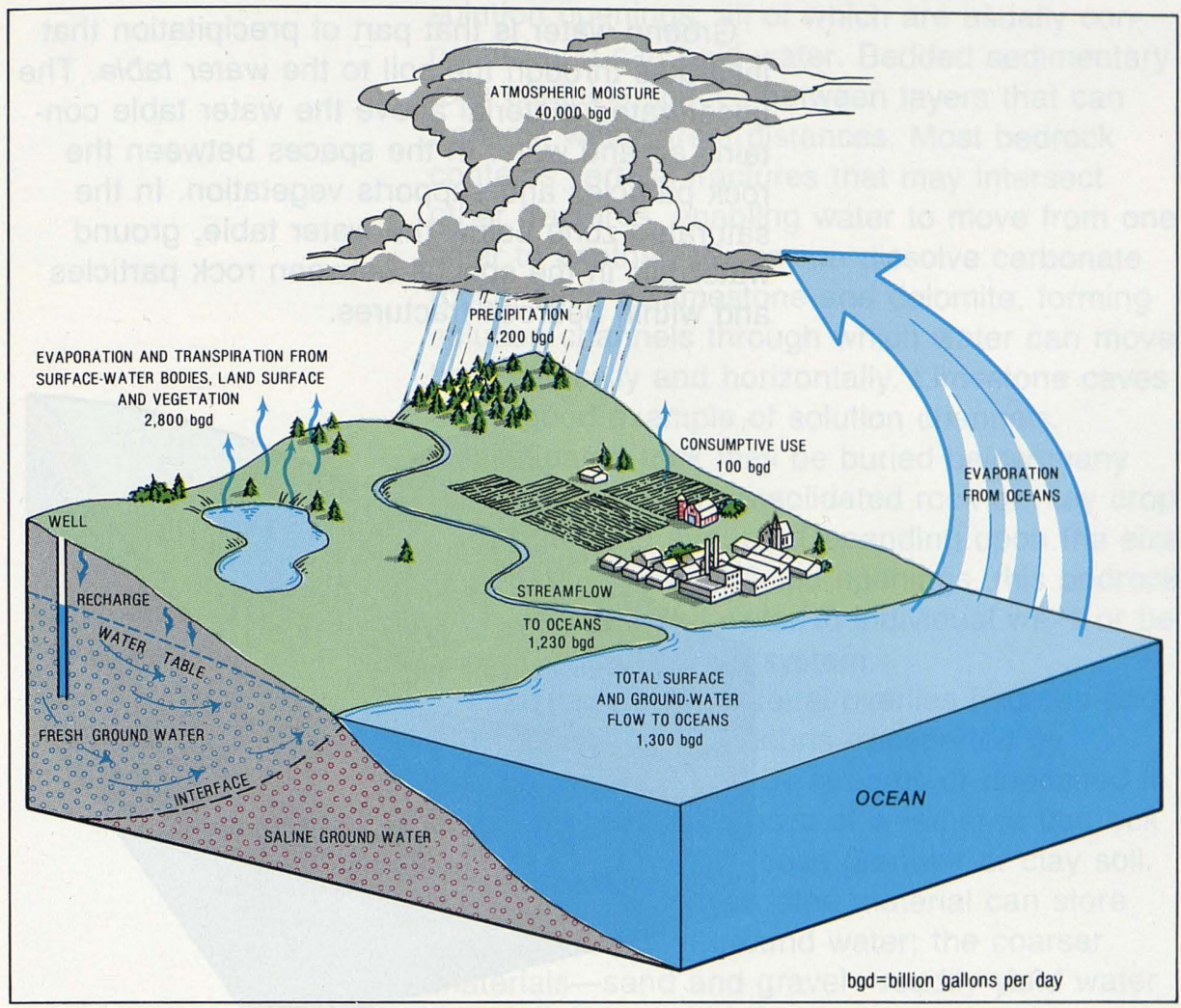

The continuous hydrologic cycle.

The hydrologic cycle is the continuous circulation of water from land and sea to the atmosphere and back again: water evaporates from oceans, lakes, and rivers into the atmosphere. This water later precipitates as rain or snow onto the land where it evaporates or runs off into streams and rivers; or it infiltrates (seeps) into the soil and rock from which some is transpired back into the atmosphere by plants. The remainder becomes ground water, which eventually seeps into streams or lakes from which it evaporates or flows to the oceans. 


\section{Ground Water}

Ground water is that part of precipitation that infiltrates through the soil to the water table. The unsaturated material above the water table contains air and water in the spaces between the rock particles and supports vegetation. In the saturated zone below the water table, ground water fills in the spaces between rock particles and within bedrock fractures.

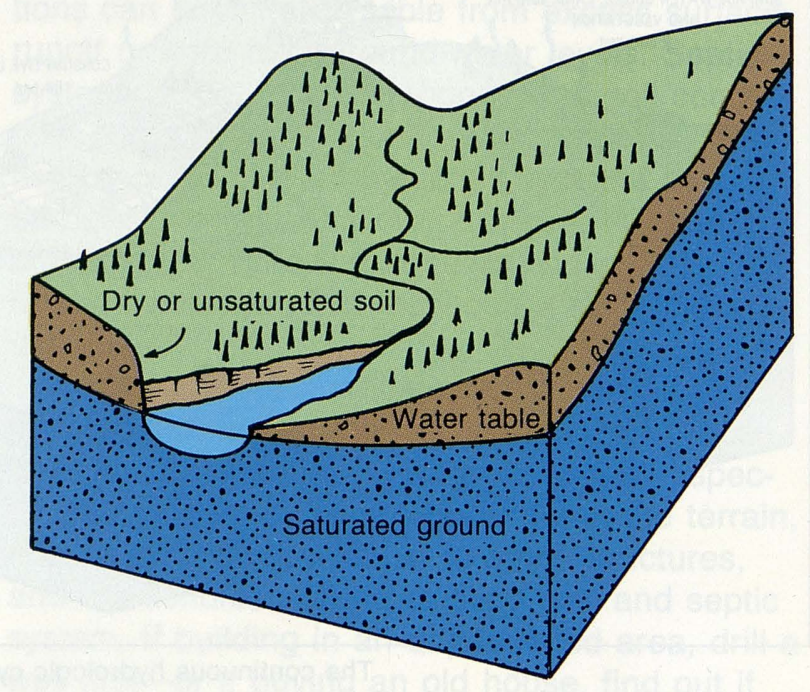

Occurrence of ground water.

\section{Where ground water occurs}

Rock materials may be classified as consolidated rock (often called bedrock) and may consist of sandstone, limestone, granite, and other rock, and as unconsolidated rock that consists of granular material such as sand, gravel, and clay. Two characteristics of all rocks that affect the presence and movement of ground water are porosity (size and amount of void spaces) and permeability (the relative ease with which water can move through spaces in the rock). 
Consolidated rock may contain fractures, small cracks, pore spaces, spaces between layers, and solution openings, all of which are usually connected and can hold water. Bedded sedimentary rock contains spaces between layers that can transmit water great distances. Most bedrock contains vertical fractures that may intersect other fractures, enabling water to move from one layer to another. Water can dissolve carbonate rocks, such as limestone and dolomite, forming solution channels through which water can move both vertically and horizontally. Limestone caves are a good example of solution channels. Consolidated rock may be buried below many hundred feet of unconsolidated rock or may crop out at the land surface. Depending upon the size and number of connected openings, this bedrock may yield plentiful water to individual wells or be a poor water-bearing system.

Unconsolidated material overlies bedrock and may consist of rock debris transported by glaciers or deposited by streams or deposited in lakes. It also may consist of weathered bedrock particles that form a loose granular or clay soil. Well-sorted unconsolidated material can store large quantites of ground water; the coarser materials-sand and gravel-readily yield water to wells.
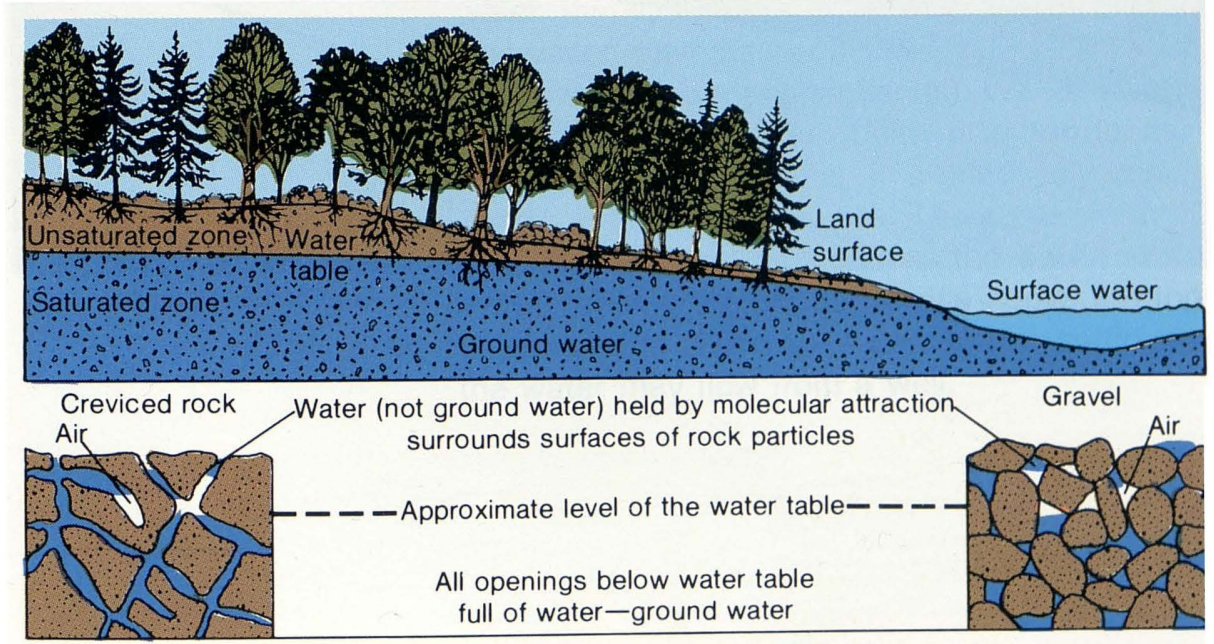

How ground water occurs in rocks. 
A close look at the rocks exposed in road cuts and along streams will show the types of openings in which ground water can occur. Especially noticeable in bedrock exposures are spaces between layers that can extend for miles-the void spaces between rock particles contain water that percolates into these spaces between the layers. In most sand and gravel deposits, water occupies and moves freely within granular material.

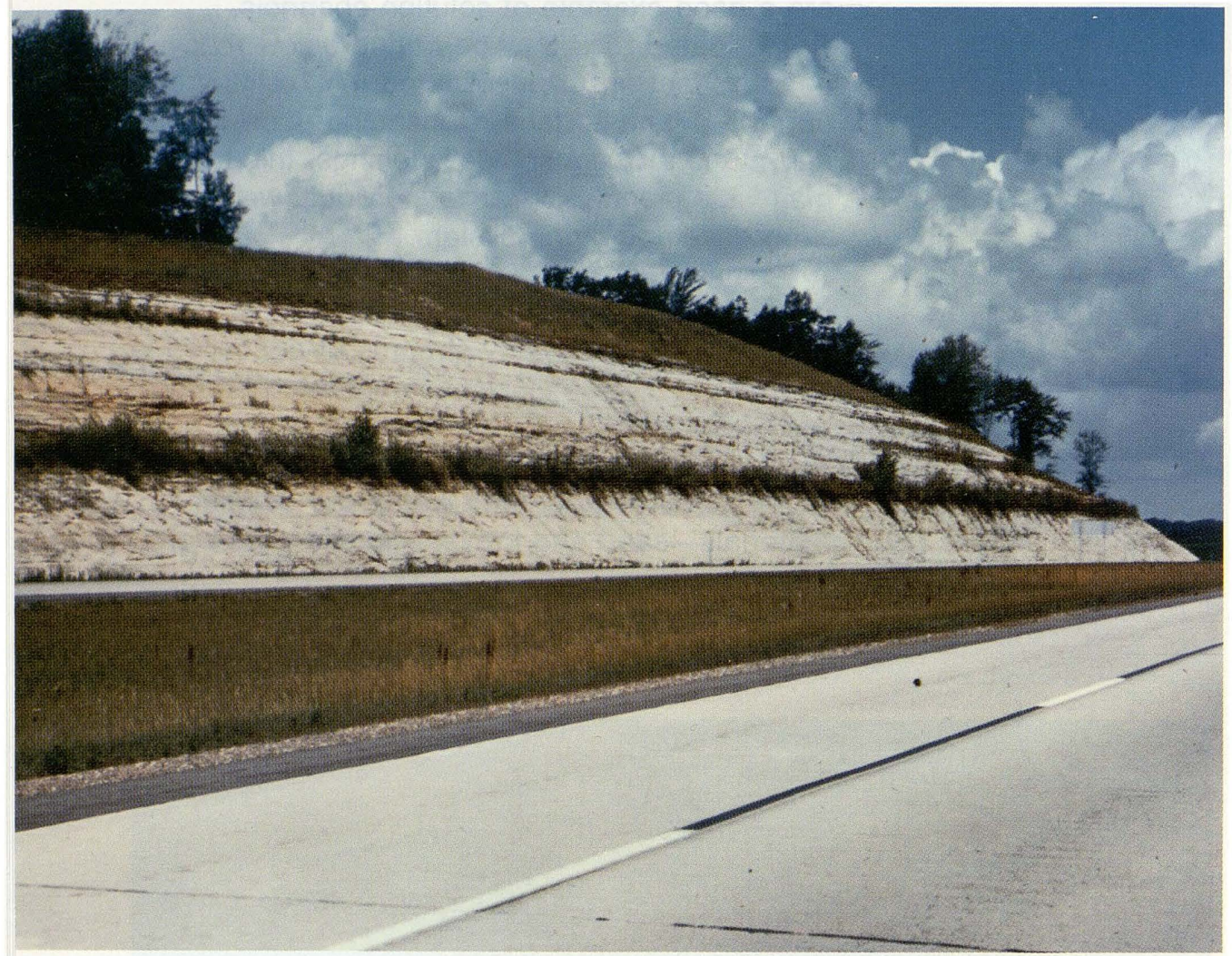

Road cuts reveal fractures, joints, and bedding planes. 


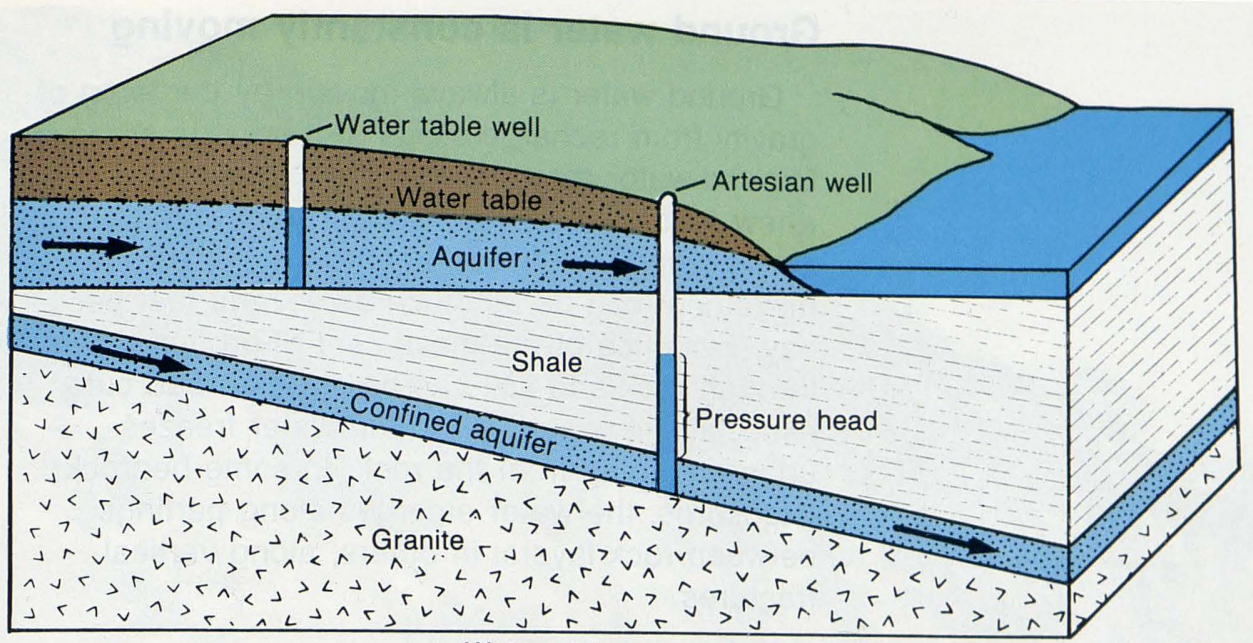

Water-table and confined (artesian) aquifers.

\section{Aquifers}

Most of the void spaces in the rocks below the water table are filled with water. Wherever these water-bearing rocks readily transmit water to wells or springs, they are called aquifers.

Although ground water can move from one aquifer into another, it generally follows the more permeable pathways within the individual aquifers from the point of recharge (areas where materials above the aquifer are permeable enough to permit infiltration of precipitation to the aquifer) to the point of discharge (areas at which the water table intersects the land surface and water leaves an aquifer by way of springs, streams, or lakes and wetlands). Where water moves beneath a layer of clay or other dense, low-permeability material, it is effectively confined, often under pressure. The pressure in most confined aquifers causes the water level in a well tapping the aquifer to rise above the top of the aquifer. Where the pressure is sufficient, the water may flow from a well. 


\section{Ground water is constantly moving}

Ground water is always moving by the force of gravity from recharge areas to discharge areas. Ground-water movement in most areas is slowa few feet per year. But, in more permeable zones, such as solution channels in limestone, movement can be as much as several feet per day. Evidence of the movement of ground water through rock and soil can be seen in road cuts, especially in winter, when the water freezes upon emerging from the rock. In some bedrock exposures, the water emerges along partings between rock layers; in others, along vertical fractures.

\section{Seasonal patterns of ground-water recharge and storage}

In latitudes where freezing is common, there is less recharge from rain or showmelt during winter, which causes the water table to fall. Sporadic or differential freezing of the soil in the fall and winter inhibits recharge to the saturated zone, and the complete freezing of the soil in winter prevents all recharge until the soil thaws in the spring.

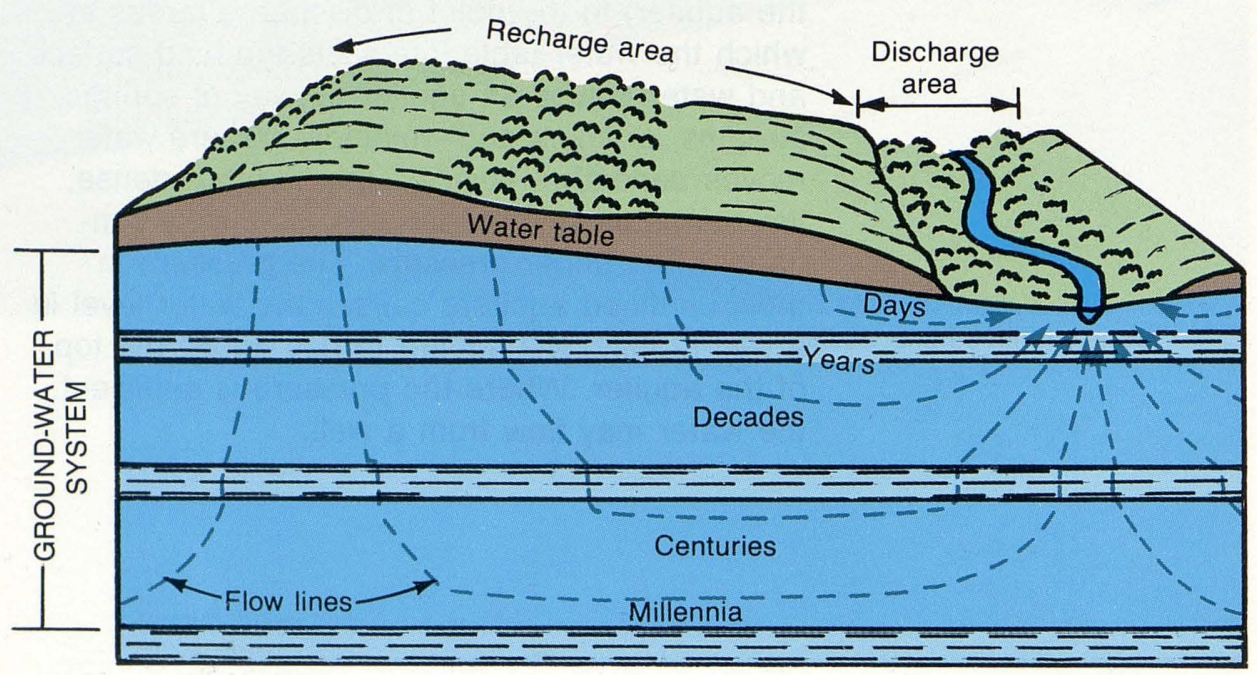

Direction and rate of ground-water movement. 


\section{Effects of long-term climatic trends on ground-water storage}

In addition to seasonal fluctuations in groundwater storage, long-term trends result from the variations in precipitation. Several years of below-normal precipitation causes a progressive decline in ground-water levels, and several years of above-normal precipitation causes a corresponding rise. These long-term climatic trends cause changes in ground-water storage. During periods of long-term, above-average precipitation, the water table may rise close to the land surface and interfere with home construction and waste disposal. For example, if a home had been built with a basement 8 feet below land surface during 1980-82 at the site of the well whose hydrograph is shown below, the basement would have been flooded in 1983 and 1984.

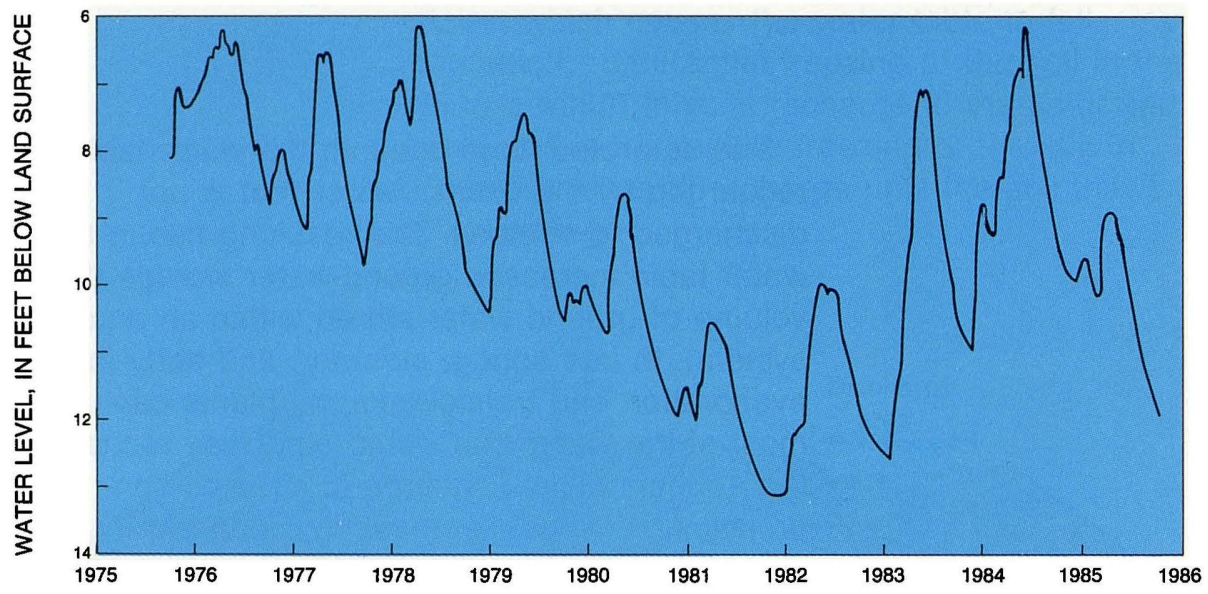

A 10-year well hydrograph showing climatic effects on ground-water level. 


\section{Types of Wells}

Most modern wells are drilled by truckmounted percussion (cable-tool) or rotary (air or hydraulic) drill rigs. Dug wells are still constructed in some areas, either by power equipment or by hand, but most hand-dug wells are the "relics" of older homes and were dug before drilling equipment was readily available or because drilling was considered too expensive. Driven wells, installed by hand or with power equipment, are still common and widely used where geologic conditions permit. Jetted and bored (augered) wells are less common types.

Types of wells.

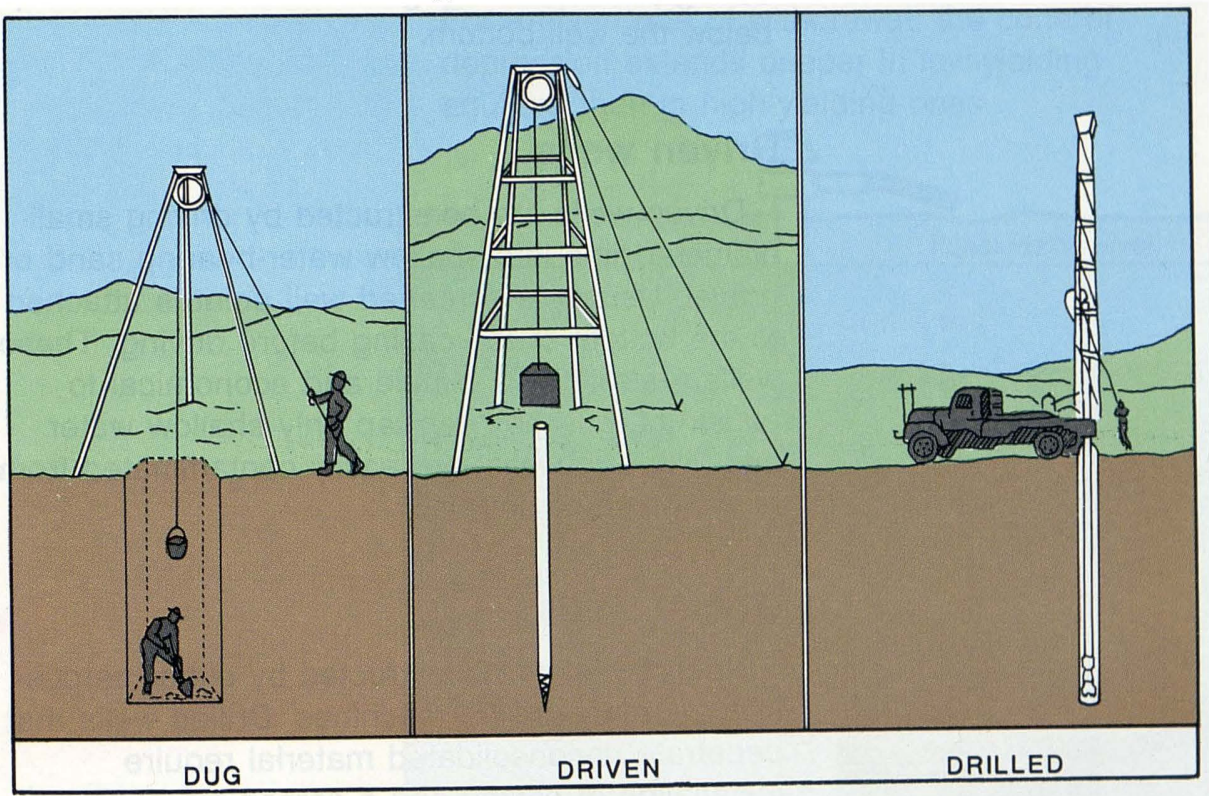




\section{Dug wells}

Historically, dug wells were excavated by hand shovel to below the water table until incoming water exceeded the digger's bailing rate. The well was lined with stones, brick, tile, or other material to prevent collapse, and was covered with a cap of wood, stone, or concrete. Modern large-diameter dug wells are dug or bored by power equipment and typically are lined with concrete tile. Because of the type of construction, bored wells can go deeper beneath the water table than can hand-dug wells.

Dug and bored wells have a large diameter and expose a large area to the aquifer. These wells are able to obtain water from lesspermeable materials such as very fine sand, silt, or clay. Some disadvantages of this type of well are that they are shallow and lack continuous casing, making them subject to contamination from nearby surface sources, and they go dry during periods of drought if the water table drops below the well bottom.

\section{Driven wells}

Driven wells are constructed by driving smalldiameter pipe into shallow water-bearing sand or gravel. Usually a screened well point is attached to the bottom of the casing before driving. These

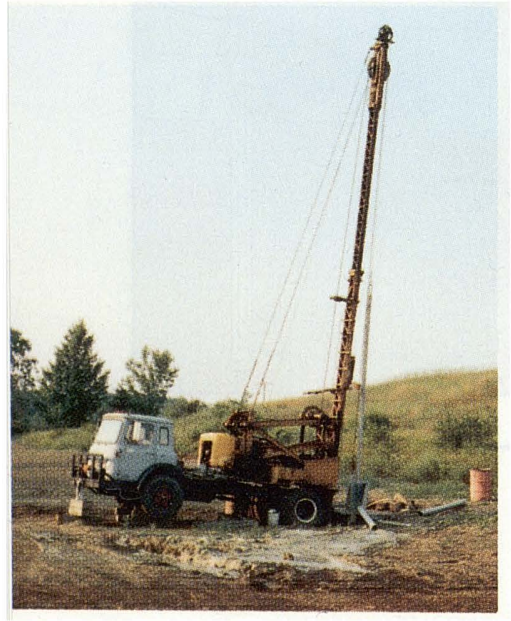

Modern truck-mounted drill rig. wells are relatively simple and economical to construct, but they can tap only shallow water and, like dug wells, are easily contaminated from nearby surface sources.

\section{Drilled wells}

Drilled wells are constructed by either percussion or rotary-drilling machines. Drilled wells that penetrate unconsolidated material require installation of casing and a screen to prevent inflow of sediment and collapse. They can be drilled more than 1,000 feet deep. To prevent contamination by water draining from the surface downward around the outside of the casing, the space around the casing must be sealed. 


\section{Wells and Pumpage}

Even though water is present at some depth at almost any location, the success of obtaining an adequate domestic supply (usually 5 gallons per minute) of water from a well depends upon the permeability of the rock. Where permeable materials are near land surface, a shallow well may be adequate. Elsewhere, such as where clayey material directly overlies bedrock, a deep well extending into bedrock may be needed.

Pumping a well lowers the water level around the well to form a cone of depression in the water table. If the cone of depression extends to other nearby wells, the water level in those wells will be lowered. The cone develops in both shallow water-table and deeper confined-aquifer systems. In the deeper confined-aquifer system, the cone of depression is indicated by a decline in the pressure and the cone spreads over a much larger area than in a water-table system. For a given rate of withdrawal, the cone of depression extends deeper in low-yielding aquifers than in high-yielding ones.

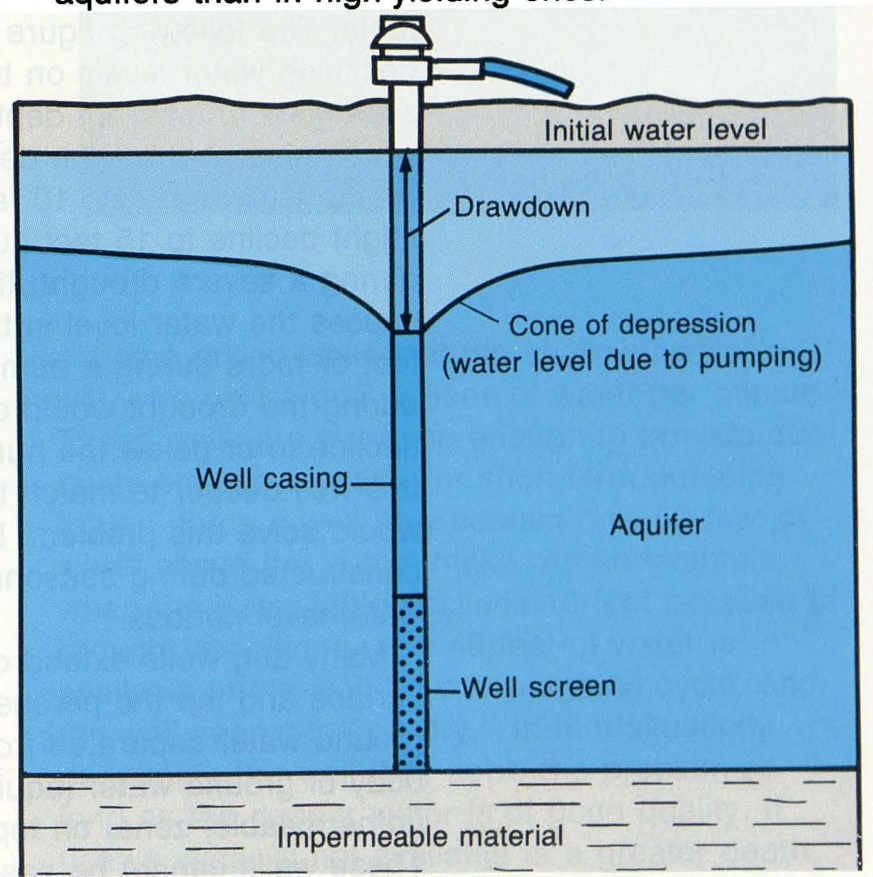

Cone of depression caused by pumping. 


\section{Water-Level Declines}

The old saying that you "never miss the water until the well runs dry" remains true; however, few drilled wells ever actually go dry. Rather, what occurs most often is that the water table has dropped to near or below the pump intake because the pump intake is not set deep enough to allow for a potential decline in water levels. Alternatively, the small strainer that covers the end of the pump intake could be partly clogged so that it takes longer to pump the same amount of water. In either case, when the pumping rate exceeds inflow to the well, air is pumped and no more water is produced until the pump is shut off and the well recovers.

\section{Shallow wells}

The most common "dry well" problem has been with dug wells. Most dug wells are shallow and excavated in poorly permeable material; consequently they are readily affected by drought or by seasonal declines in the water table. The following figure shows the effect of declining water levels on two adjacent wells that are drilled to different depths on either side of a water-table pond. If the depth to water in the well on the left were, say, 10 feet during spring, it might decline to 15 feet during late summer or during a severe drought. If the pump normally causes the water level in the well to decline 5 feet or more during a pumping cycle, pumping during the drought would cause the water to decline to or below the pump intake. Excavating this well deeper to match the well on the right would solve this problem. Dug wells should be constructed during seasonal or climatically lowwater-level periods.

Many dug wells extend only to the bedrock surface and tap the perched water (unconfined ground water separated from an underlying main body of ground water (aquifer) by an unsaturated (impermeable) zone) on top of the bedrock. These wells cannot be easily deepened. In such cases a new drilled well is the only long-term solution. 


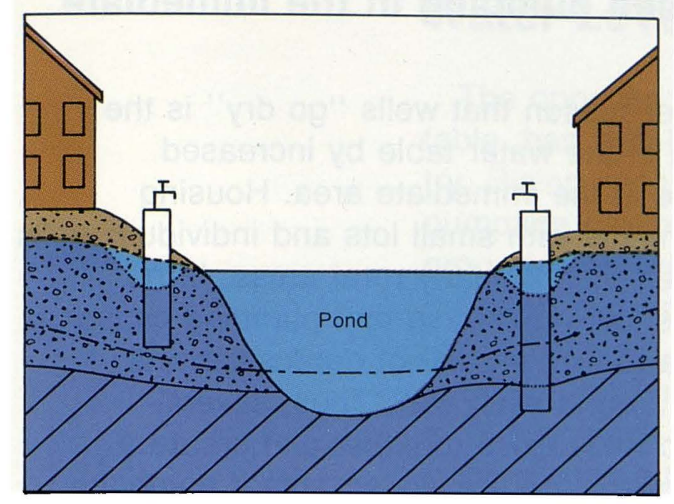

How does a well go dry?

EXPLANATION

- High water table

............... Pumping leve

Pond level

Solving a drought-related water shortage by deepening the well.

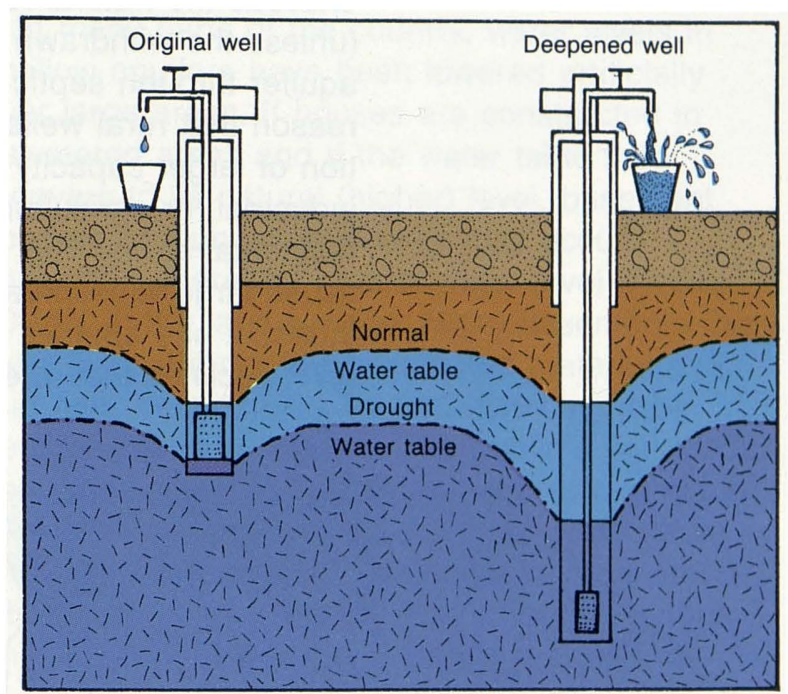

Some drilled wells that tap shallow bedrock will yield only 1 or 2 gallons of water per minute. These wells are not deep enough to provide adequate storage of water for short-term pumping cycles. Such a well may contain only 50 feet of water above the pump intake. As an example, when the water table declines 10 feet because of drought conditions, only 40 feet of water is available in the well for one pumping cycle, and the well seems to "go dry." In that situation, deepening the well may solve the problem as long as the deeper water is of good quality. If usable water is not available at a greater depth, the pumping rate must be reduced so that less water is pumped during each cycle. 


\section{Increased pumping in the immediate area}

Another reason that wells "go dry" is the lowering of the water table by increased pumpage in the immediate area. Housing developments with small lots and individual wells have been built in many rural areas. If the aquifer is low yielding so that pumping causes a large drawdown, a cone of depression will develop around each well. Thus, several domestic wells close together can create a steady lowering of the water table if pumpage exceeds the natural recharge to the system (unless the withdrawn water is returned to the aquifer through septic systems). A third major reason that rural wells "go dry" is the installation of larger capacity wells for municipal, industrial, or agricultural purposes adjacent to residental areas. The increased withdrawals may cause large widespread cones of depression that intersect one another and cause general waterlevel declines that affect nearby domestic wells.

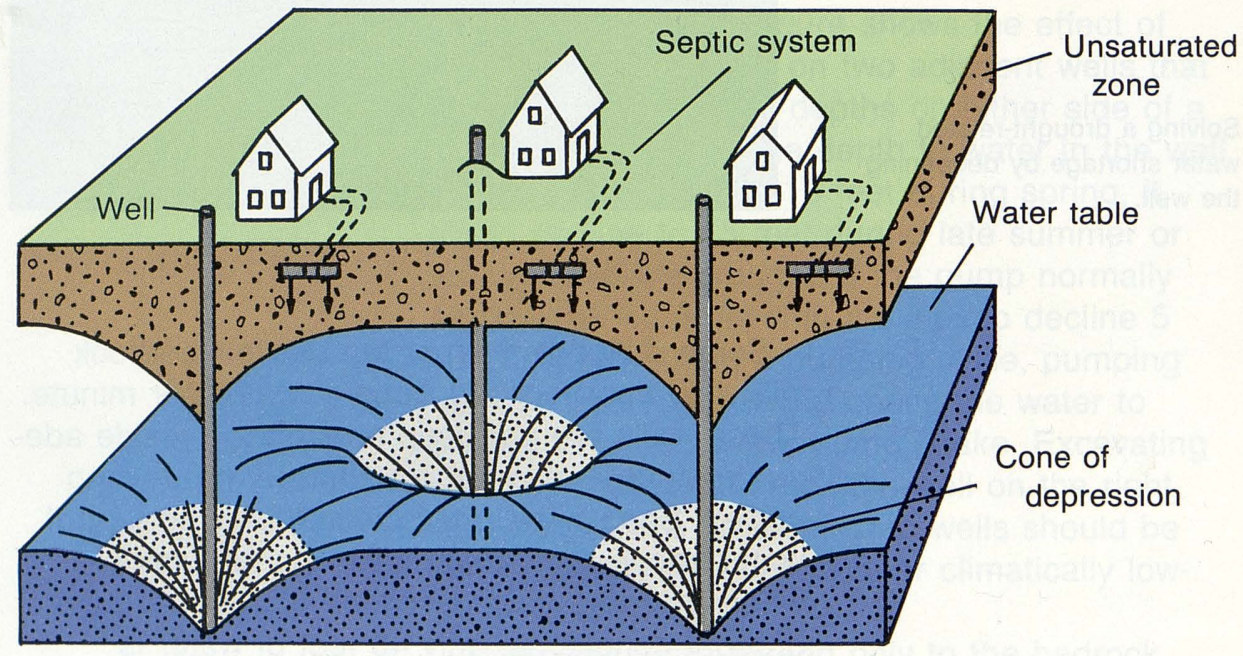

Effect of concentrated housing on ground-water level. 


\section{Water-Level Rises}

The opposite problem, namely a rising water table, has developed in some parts of the country. Rising water tables occur in areas where pumpage has been curtailed after years of large ground-water withdrawals, such as for mine dewatering or municipal water supply, which kept the water table below its natural levels. The curtailment of pumping allows the water table to rise to the previous natural level, which may flood underground structures that were built when the water table was lowered.

In many parts of the country, water levels in shallow aquifers have been lowered artificially over large areas. If houses are constructed in dewatered areas and if the water table then recovers to its natural (higher) level, basement flooding or foundation failures may occur, especially where the natural water level is within 10 feet of the land surface. Many basements that were built in a dry unconsolidated material and that had remained dry for decades have now become permanently wet. The public's first reaction may be that unusually heavy precipitation in the past few months has raised the water table or created a temporary perched-water system, when in fact the situation is much more serious and will remain a problem unless pumping is resumed to maintain a lower water table.

Where water levels are closely monitored, water-level records can indicate whether such high water levels are related solely to climatic events or whether water levels are recovering after nearby pumping has ceased. An increasing number of local areas are being dewatered for mining or industrial uses, which could cause serious problems in the future when such pumpage is decreased or ended.

Similar situations have occurred where housing developments were built during a period of extended drought when the water table was low. Even if basements were the "daylight" or raised type because the natural water table was shallow, the eventual return of a wet period caused the water table to rise a few feet and flood basements. 


\section{Quality of Water}

Some common ground-water quality concerns are excessive hardness (high dissolved magnesium and calcium content), a high concentration of salt or iron, or the presence of hydrogen sulfide (sulfur), methane gas, petroleum or organic compounds, or bacteria. Some are naturally occurring; others are introduced by human activities. In many areas, the homeowner has little recourse other than to use chemical treatment to remove or reduce the level of these constituents or to abandon the water supply. Hardness, iron, and sulfur are common constituents that can be treated.

\section{Salt contamination}

Salt contamination is difficult and expensive to remedy unless the well drawing saline water from a deep aquifer also pẹnetrates one or more freshwater aquifers at lesser depth. In such cases, the deep saline aquifer can be sealed off and the well can be drilled in the freshwater aquifer instead. In many parts of the country, however, when a well is drilled deeper into bedrock to obtain larger supplies, saline water is more likely encountered than additional freshwater is.

Road-salt contamination of ground water has increased in the last 30 years and is of major concern in northern areas. Highway departments mix salt with sand to spread on roads for deicing. Salt is readily soluble in water and runs off highways into lakes and streams and percolates to the water table.

Probably more serious than the spreading is the stockpiling of uncovered salt and sand mixtures. This practice produces concentrated saltwater runoff that percolates to underlying aquifers and nearby wells. Many stockpiles are within small villages or near housing areas where nearby domestic wells can become contaminated. 
Leachate from sand and salt stockpiles is a potential source of contamination to shallow ground water.

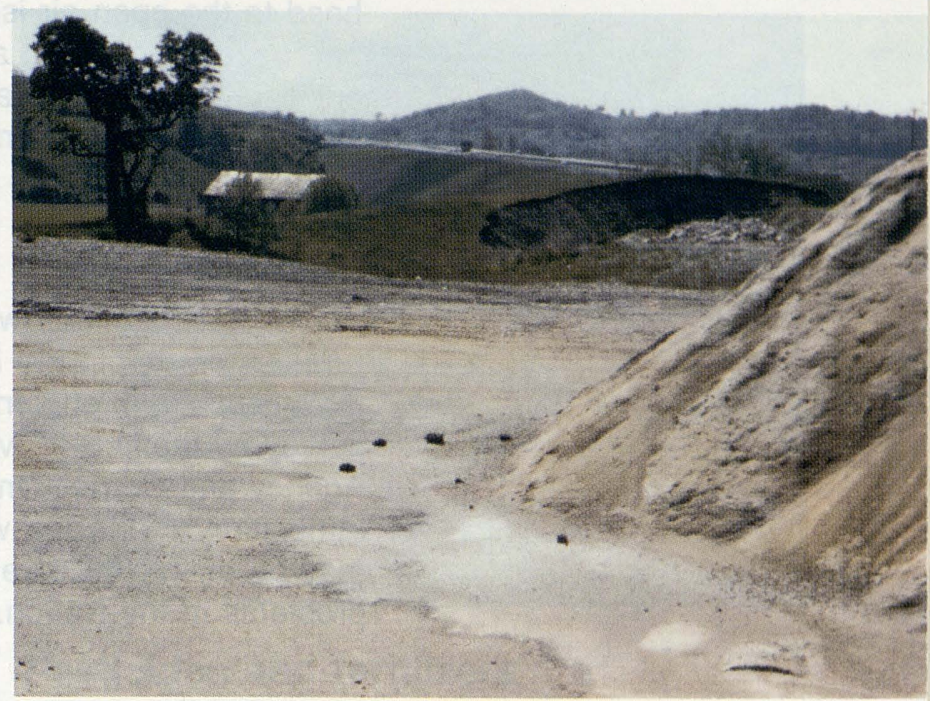

\section{Oil spills}

Another chronic problem in many rural homes is leaking or spilled fuel oil which eventually contaminates the owner's own well. Many homes have a fuel tank, either buried or above ground, adjacent to the house and within a few feet of the well. Spills or accumulated leakage eventually can migrate to the aquifer and can be drawn into the well, making it unusable for years.

Usually the only solution is to obtain a new water source. In some instances, however, reducing the pumping rate to reduce drawdown allows the oil to float on the water surface safely above the well's intake area.

\section{Methane gas}

Perhaps the problem that poses the greatest hazard to a well owner is flammable gas in the well. Small volumes of natural gas, usually methane, can be carried along with the water into wells tapping carbonate or shale rock. In some areas, the gas dissipates soon after installation of the well, but, in other areas, a large continual source of natural gas remains. Because methane is flammable and cannot be detected by smell, precautions are needed to prevent explosions and fire. Venting of the well 
head to the open air is the simplest precaution but, because gas can also accumulate in pump enclosures, pressure tanks, and basements, other venting may be needed. For this reason, a home should never be built over a well.

\section{Bacteria}

The most common water-quality problem in rural water supplies is bacterial contamination from septic-tank effluent. A recent nationwide survey by the U.S. Environmental Protection Agency and Cornell University found that contamination of drinking water by septic effluent may be one of the foremost water-quality problems in the Nation.

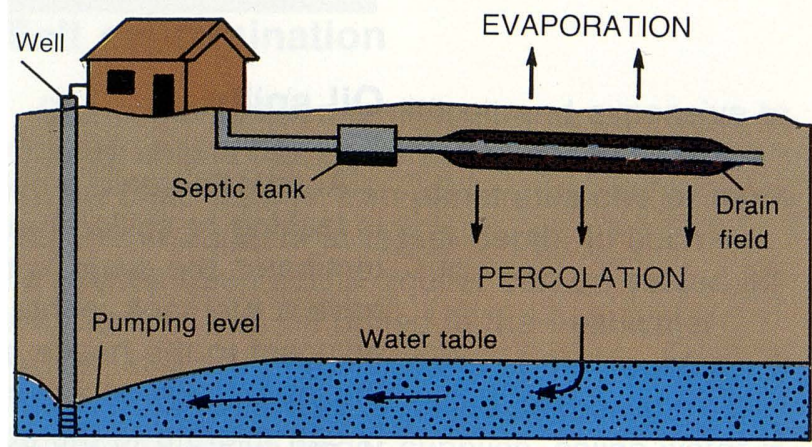

How septic effluent percolates to the water table.

\section{Barnyard runoff}

Probably the second most serious watercontamination problem in rural farm homes is from barnyard waste. If the barnyard is upslope from the well, barnyard waste that infiltrates to the aquifer may reach the well. Pumping, too, can cause migration of contaminants to the well. On many farmsteads built more than 100 years ago, the builders were careful to place the supply well upslope from the barnyard. Unfortunately, many present-day owners have not remembered this basic principle and have constructed a new house and well downslope of the barnyard. 
Barnyard upslope from farmhouse well may cause bacterial contamination of water supply. (Photograph courtesy Cornell University.)

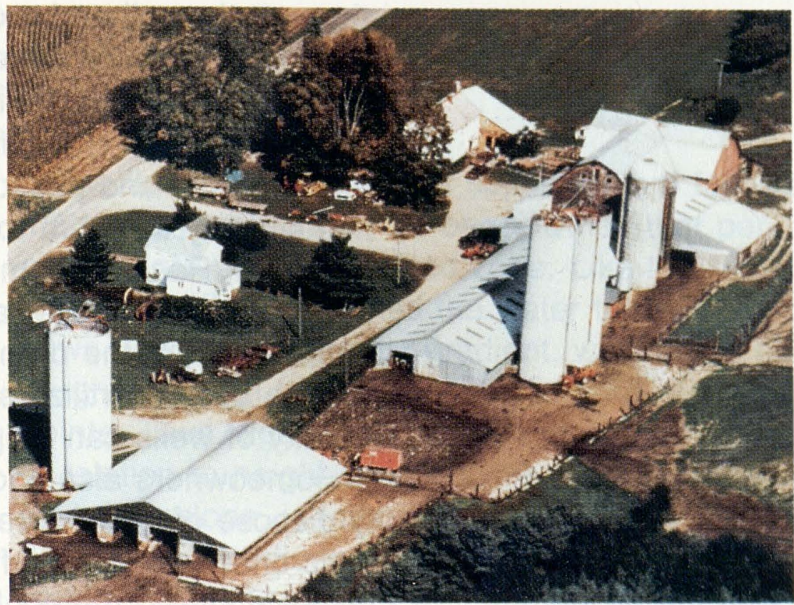

Pesticides and fertilizers

The last 3 decades have seen a significant increase in small part-time farms and rural dwellings as large farms have been sold and divided into smaller units. Many modern rural homes are constructed on former cropland on which heavy applications of herbicides and fertilizers may have been made. How these chemicals move

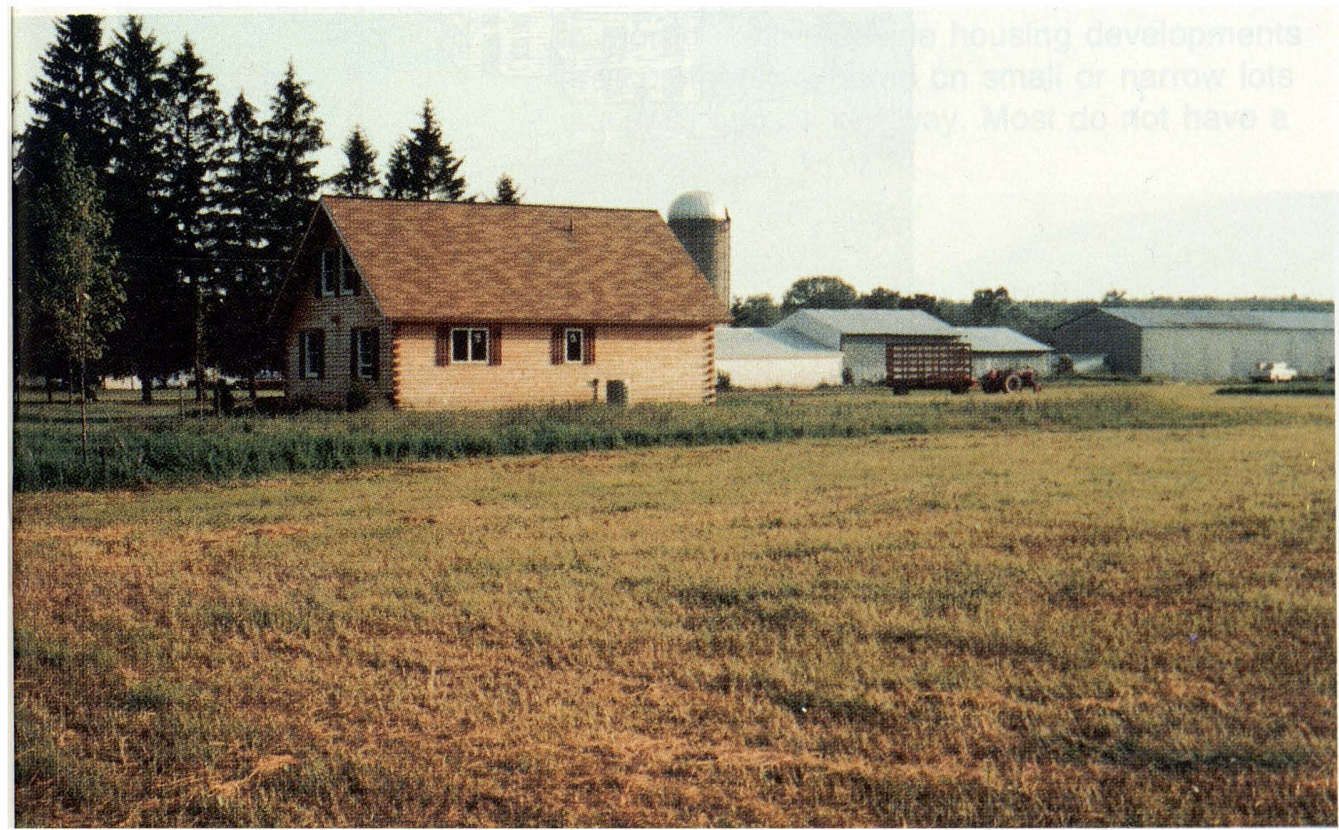

New home on land recently used for crops. 
through the soil and ground water and how quickly they decompose or how their harmful effects are neutralized is not well understood.

Also common is the farming practice of applying fertilizers and pesticides to croplands immediately adjacent to the barnyard or farmyard. Residue from these applications can infiltrate to the aquifer and can be drawn into a supply well for the barn or the house. Decreasing the use of fertilizers and pesticides in the vicinity of wells can help minimize this problem.

Homeowners also should be careful to properly dispose of wastewater from used containers of toxic chemicals. Many farms have their own disposal sites, commonly pits or a wooded area, for garbage and the boxes, sacks, bottles, cans, and drums that contained chemicals. Unfortunately, these owner disposal sites can contaminate farm water supplies.

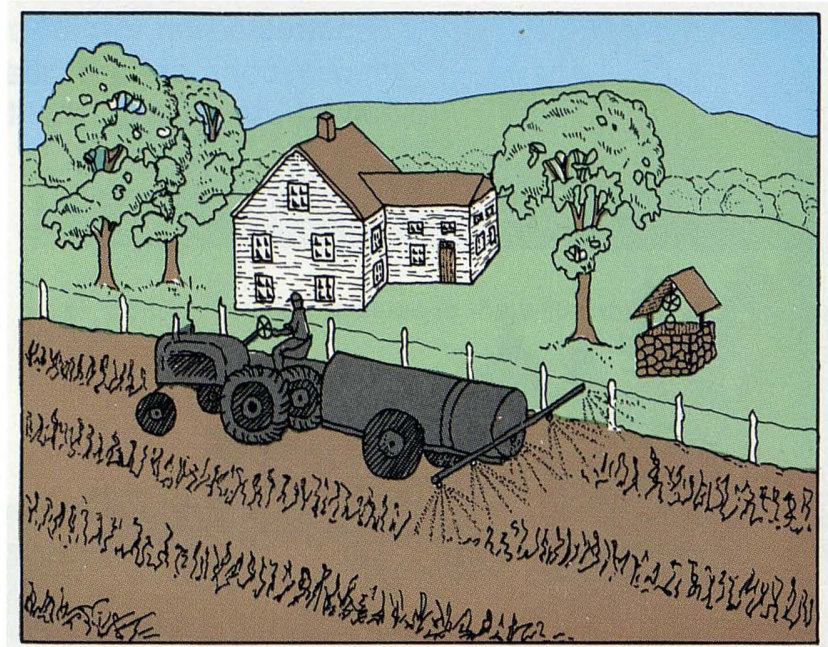

Pesticide spraying near well. 


\section{Septic Systems and Ground Water}

The liquid effluent from a septic system follows the same path as the rain or snowmelt that percolates into the unsaturated zone. Like the rain, once the effluent reaches the water table, it flows down the hydraulic gradient, which may be roughly parallel to the slope of the land, to lower points. Thus, again, the location of one's house in relation to neighboring houses, both upslope and downslope, is important.

Septic-tank effluent that enters the aquifer supplying the homeowner's well introduces not only bacteria but also other contaminants. Many rural homeowners also discharge other waste products, including toxic material, into their septic systems, and these products gradually accumulate in the aquifer. What happens to these contaminants in the ground is not well known. Some adhere to rock material, others travel with the water. In some types of rock material, the leach field or dry-well part of the septic system can gradually become clogged by contaminants.

Rural homes in small, older communities and in more recent roadside housing developments are commonly situated on small or narrow lots along an access highway. Most do not have a

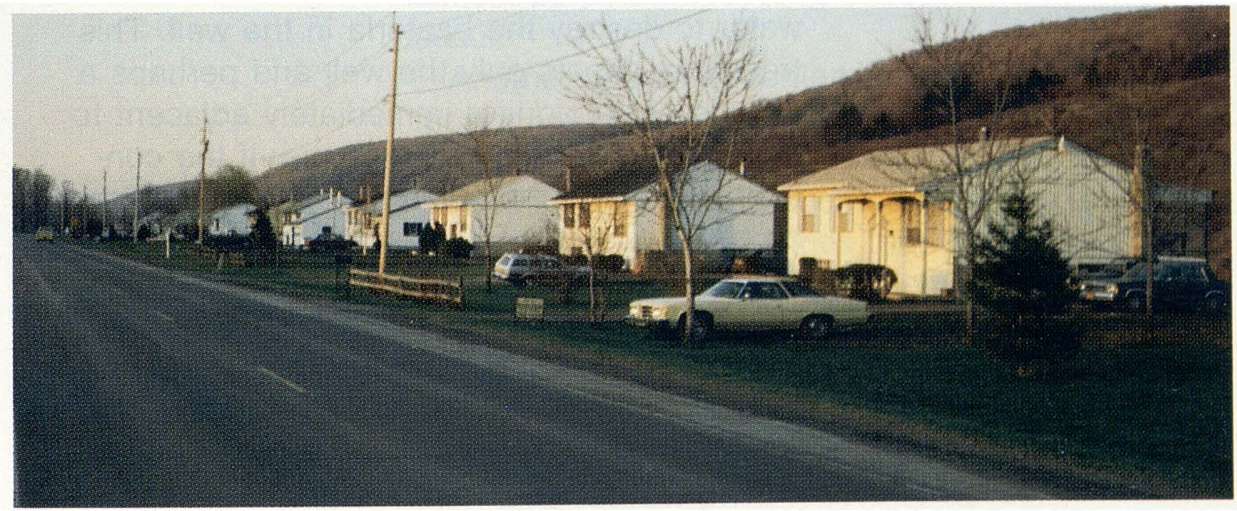

Rural roadside housing development. 
community water supply, and almost all have their own individual septic systems. In clusters such as this, effluent recycling can occur if the wells are shallow or the septic systems are improperly placed. Deep wells are less likely to draw in septic waste.

This type of effluent problem becomes acute in an area underlain by a shallow water-table aquifer where the septic effluent discharges into water that is used by many homeowners. This dilemma has been posed in many rural housing developments throughout the Nation. One either "fouls his own nest" with effluent or connects to a central sewer system. Although a sewer system protects the aquifer from further contamination, it reduces recharge of water to the aquifer. This engineering, economic, and social dilemma must be resolved soon in many areas. An increasing number of counties and townships are planning and zoning rural areas to limit the density of houses according to soil conditions. Other approaches being considered are a community water supply with individual septic systems or individual water supplies with a community sewer system.

Some banks and lenders require that the prospective buyer or the seller furnish proof of a bacteria-free water supply before they will issue a mortgage. When a seller faces such a requirement, a common procedure is to chlorinate the water to destroy the bacteria in the well. This treatment affects only the well and perhaps a volume of the aquifer immediately adjacent to the well, but for only a brief time. If the contamination is in the aquifer, the source will not be attacked nor the problem solved; thus a water analysis showing bacteria-free water immediately after the well has been disinfected is not necessarily an assurance of a safe water supply. The homeowner should periodically have the water analyzed for bacteria. If a high bacteria count occurs repeatedly, the problem is probably in the water source, and chemical treatment of the well alone cannot solve it.

In a bacteria-contaminated water system, chlorination of the water pumped from the well is commonly recommended as a solution. Other- 
wise, one must obtain a water supply from a new well that either is upgradient from the contaminating source or that taps a deeper aquifer. Moving the septic system to a more distant spot is a long-term solution, but the underlying contaminated zone may take years to stop releasing contaminants to the aquifer.

\section{Cluster-housing contamination}

In a row-housing setting, the house at the highest location will generally have the safer water supply. Because the effluent migrates down beneath the development, it could be pumped, used, and again discharged by each house along its course. The house furthest downslope would receive the combined effluent from the other houses.

Another contamination problem from closely spaced septic systems can occur where a row of houses on the uphill side of a road faces a row of houses on the downhill side of the road. Here, the safer water supply would be on the uphill side. The downhill side would receive effluent from the uphill side plus any contamination generated along the road, such as road salt or metal compounds. In flat areas underlain by a shallow water table, especially where cluster developments are two or more decades old, almost perpetual recycling of septic waste may occur.

Another source of contamination that is common in villages or hamlets lacking a central water or sewage system is small wastegenerating businesses such as laundries, autorepair shops, and industries that discharge wastes to their own septic systems. Many of the bacterial problems, cited in a recent U.S. Environmental Protection Agency rural water study, were in hamlets, villages, or crossroads communities. Once indoor plumbing became common and outdoor privies were removed, all waste went into septic systems from which increased amounts of liquid effluent eventually entered the aquifer and became subject to pumping by wells. 


\section{Former orchards or vegetable lands}

Individual homes and developments alike have been built on former orchards or vegetable farms. Although these lands can be picturesque where fruit trees remain, one must remember that pesticides and chemical fertilizers probably were applied heavily in the past. The fate of many of these chemicals in the soil is unknown, and long-term contamination may remain, especially in the shallow ground water. The soil through which recharge from precipitation moves is the repository for much of the chemicals that are deposited on the land. Decades may pass before these chemicals are dissipated or flushed away. Therefore, anyone planning to buy or build a house on a former orchard or truck farm should consult farm or zoning agencies to obtain information on the potential for pesticide and fertilizer residue.

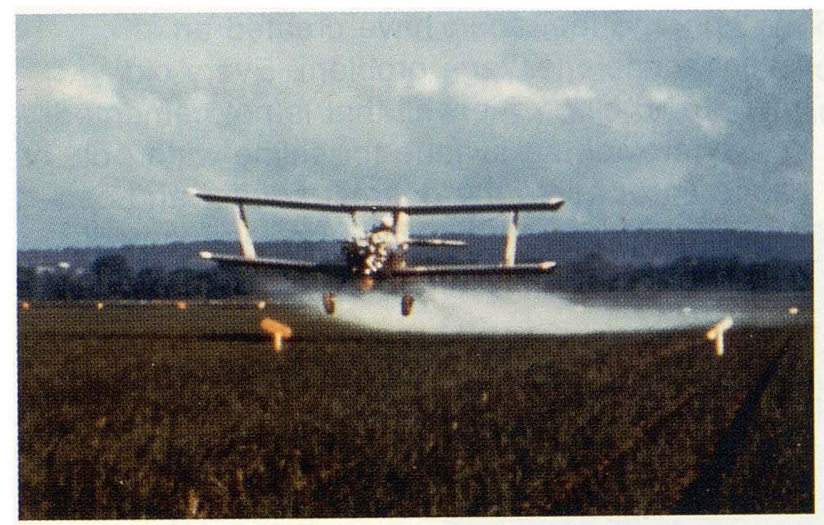

Crop dusting and orchard spraying. (Photographs courtesy Cornell University.)

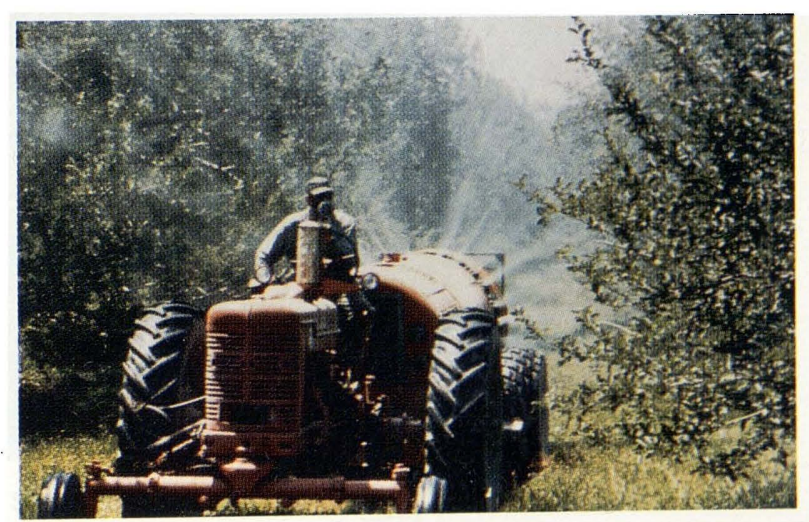




\section{Oil and gas fields}

Oil and gas development has occurred and is occurring in many parts of the country. Oil and gas development almost always includes the production of brine or saline water, which then must be disposed of. Most states regulate the disposal of brine to prevent contamination of surface and ground water, but, in old oil and gas fields that were abandoned before extensive regulation, saline water is still escaping from improperly sealed or cased wells into freshwater aquifers.

One method of producing more oil or gas from old fields is to inject water or brine into the producing formation to increase the pressure and move the oil or gas to wells. Some oil or gas fields are "leaking," however, and once the pressure is increased, the injected fluid or oil finds avenues of escape to other formations, such as through abandoned boreholes or corroded well casings. Some shallow producing areas that contain many abandoned wells spaced a few hundred feet apart have created an unmanageable leakage problem. Every old abandoned oil or gas well that is not cementedin may provide an avenue for saline water, oil, or gas to escape into the nearest aquifer and contaminate the system. It would be wise to verify that the home being purchased is not near an old oil or gas field. 


\section{Subsidence and sinkholes}

Land subsidence occurs where large amounts of ground water have been withdrawn from a thick layer of saturated fine-grained sediment that is susceptible to compaction. General subsidence is not noticeable in some large areas, but in others, concentric cracks develop over smaller areas where compaction is occurring.

Sinkholes are common where the land is underlain by limestone or other carbonate rocks that are naturally dissolved through ground-water circulation. A sinkhole can also develop where salt beds occur beneath the land surface. As the limestone or salt is dissolved naturally by ground water or by industrial solution-mining of the salt, the overlying material can collapse into the resulting cavern. In worst cases, such collapses create a.large sinkhole that will topple or swallow any structure above it. Housing development should be avoided in sinkhole-prone areas. Although it is difficult for an individual to discern the exact locations of potential sinkholes, areas prone to sinkhole development are generally well known by State geological surveys.

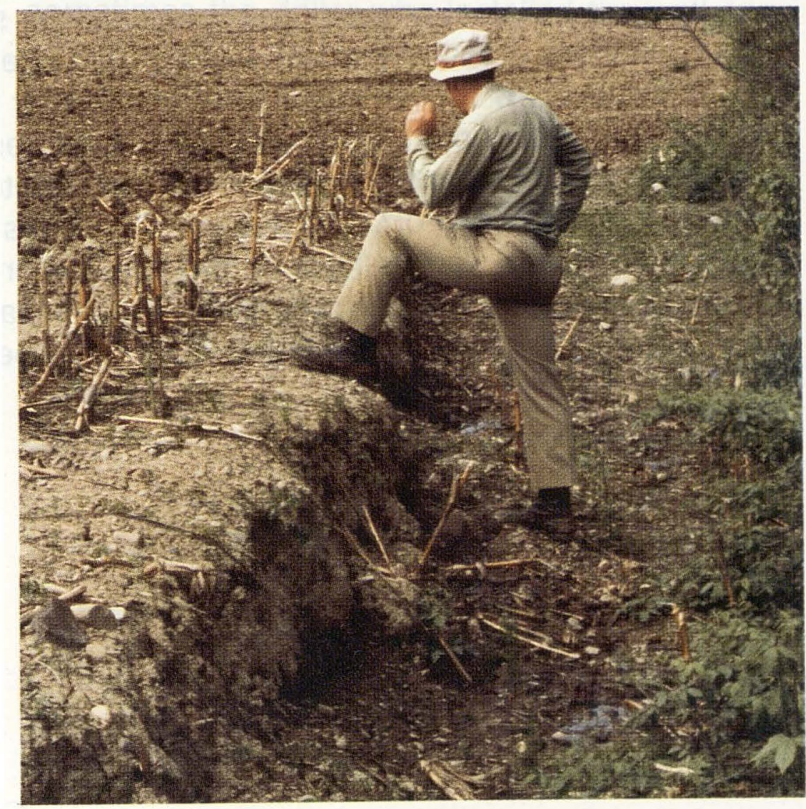

Sinking land ruins croplands. 


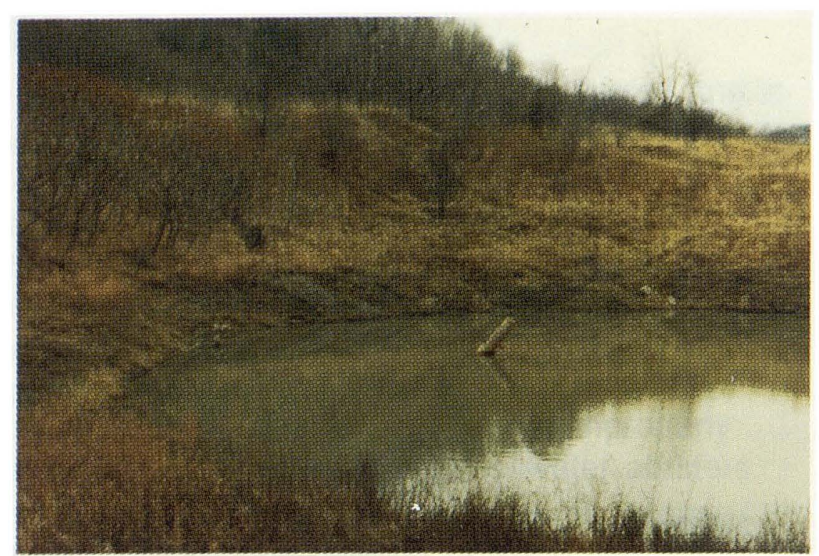

Sinkholes develop suddenly.

\section{Consider Past and Future Land Use}

The preceding section highlighted some of the contamination hazards that may be attributed to previous land uses. One way to obtain information on previous land use is to contact local county or town planning or zoning boards. Their records may show that land was formerly used for agriculture, landfill, or industrial/mining purposes. Land owners can then better evalute what past land-use practices should be considered in planning future land use.

Similarly, land-use or zoning maps can show where planners have designated uses that may be considered detrimental to home ownership. Many planning agencies have evaluated and classified the land for preferred and alternate uses. Consult these local agencies before building or buying in specific areas. 


\section{Country Living Calls for Knowledge}

Before purchasing a home in a rural area, the buyer should determine the amount and quality of water and should locate the waste-disposal system.

\section{A well log and a water analysis may be as important as a deed}

As ground water receives increasing attention nationwide, particularly because of toxic-chemical contamination, a written legal document verifying an adequate water supply from new or old wells is becoming important. Some mortgage lenders require a negative bacterial analysis of the water and a yield test of the well to verify an adequate supply. As mentioned earlier, a single analysis for bacteria may not reflect true conditions, but it is worthwhile to have it done nevertheless.

A well record (driller's log) describes the well characteristics, including yield and the type of material that the driller encountered. The well log is not always available from the owner, and sometimes the driller who installed the well cannot be located. If the well log is available, however, it can be helpful. If water quantity becomes insufficient, a record of a yield test is helpful in determining what happened. Most dug wells, of course, have no description other than depth. In any case, it is wise to obtain information on well depth, water level, type of pump, pump-intake setting, and yield before buying a house. 


\section{Determine the location of the septic system and water source}

The buyer of rural property must know the location of the water source and the wastedisposal system to evaluate the potential for certain problems. Even a cursory glance at their location, distance from each other, and the land slope often provides an initial estimate as to their adequacy. For example, evidence of two or more wells or septic systems warrants a detailed inquiry. An odor of sewage, a wet area, or lush grass over a leach field, especially during dry periods, indicates a potential problem.

\section{Some Practical Considerations}

As stated earlier, learn as much as you can about the land, the water supply, and the septic system of the house before you buy. Be sure to consider the environmental conditions, and try also to visit the site during bad weather. Don't be rushed-take time to be informed.

Most rural water problems are related to old dug wells, septic systems, and too-dense housing developments. Drilled or deep wells are generally less susceptible to sewage or surfacecontamination sources than shallow wells are, but water from bedrock wells is more likely to contain gas or minerals than is water from shallow deposits. Most well drillers are aware of common local problems and generally locate wells properly.

Although potential water problems for the rural homeowner can sometimes be expensive, pose a health hazard, or possibly affect real estate values, these problems can be avoided by the observant, informed buyer or owner. 
Table 1. Water factors to consider in buying or building a new home

\begin{tabular}{|c|c|c|}
\hline Problem & Probable cause & $\begin{array}{l}\text { Remedy or } \\
\text { source of help }\end{array}$ \\
\hline Inadequate water yield & $\begin{array}{l}\text { Poor aquifer } \\
\text { Well screen or pump intake encrusted } \\
\text { Lower water level }\end{array}$ & $\begin{array}{l}\text { Install larger, deeper well } \\
\text { Have cleaned by well driller } \\
\text { Deepen well } \\
\text { Contact water resources agency }\end{array}$ \\
\hline Wet basement & $\begin{array}{l}\text { Seasonally high water table } \\
\text { Recovered water level } \\
\text { Drainage from roof or slope }\end{array}$ & $\begin{array}{l}\text { Add sump pump or drains } \\
\text { Add sump pump or drains } \\
\text { Add roof gutter, reslope land } \\
\text { Contact Soil Conservation Service }\end{array}$ \\
\hline Gas in water & Methane from bedrock & $\begin{array}{l}\text { Install vent on well head } \\
\text { Aerate the water } \\
\text { Install water treatment } \\
\text { Drill new well away from house } \\
\text { Contact State geological survey }\end{array}$ \\
\hline Salty water & Road salting & $\begin{array}{l}\text { Install new well farther upslope } \\
\text { Provide better road drainage }\end{array}$ \\
\hline & Road-salt stockpile & $\begin{array}{l}\text { Install new well away from drainage } \\
\text { Request correction by highway } \\
\text { department } \\
\text { Contact health department }\end{array}$ \\
\hline Fuel-oil contamination & Leaky or spilled storage tank & $\begin{array}{l}\text { Install new well upslope } \\
\text { Adjust to low pumping rate }\end{array}$ \\
\hline $\begin{array}{l}\text { Oil or gasoline } \\
\text { contamination }\end{array}$ & Nearby service station & $\begin{array}{l}\text { Obtain new source of water } \\
\text { Contact health department }\end{array}$ \\
\hline \multirow[t]{2}{*}{ Bacteria contamination } & Septic effluent & $\begin{array}{l}\text { Chlorinate as first step; contact health } \\
\text { department } \\
\text { Install new well upslope } \\
\text { Install new leach field farther away } \\
\text { Deepen well in some cases } \\
\text { Seek control on neighboring system }\end{array}$ \\
\hline & Barnyard waste & $\begin{array}{l}\text { Redirect waste flow } \\
\text { Install new well upslope } \\
\text { Seek control on neighbor's activity } \\
\text { Contact agricultural agency }\end{array}$ \\
\hline $\begin{array}{l}\text { Organic chemical } \\
\text { contamination }\end{array}$ & Former land use & $\begin{array}{l}\text { Install new well farther away } \\
\text { Deepen well in some cases } \\
\text { Contact health department }\end{array}$ \\
\hline & Current land application & $\begin{array}{l}\text { Create buffer zone around recharge } \\
\text { area } \\
\text { Dispose of wash water properly } \\
\text { Seek control on neighbor's activity } \\
\text { Contact health department }\end{array}$ \\
\hline Land Subsidence & $\begin{array}{l}\text { Excessive ground-water withdrawal } \\
\text { Rock solution }\end{array}$ & $\begin{array}{l}\text { Contact State regulatory agency } \\
\text { Relocate house } \\
\text { Contact State geological survey }\end{array}$ \\
\hline Sinkhole development & Rock solution & $\begin{array}{l}\text { Relocate house } \\
\text { Contact State geological survey }\end{array}$ \\
\hline $\begin{array}{l}\text { Source of ground } \\
\text { water unknown }\end{array}$ & $\begin{array}{l}\text { No knowledge } \\
\text { No well data available }\end{array}$ & $\begin{array}{l}\text { Contact water resource agency } \\
\text { Contact water resource agency }\end{array}$ \\
\hline
\end{tabular}


Table 2. Sources of information

Geologic conditions and mining areas

State geological surveys

State bureaus of mines

State natural resources agencies

U.S. Geological Survey

Soils, drainage, and agricultural uses

U.S. Department of Agriculture

State land-grant colleges

County extension agents

Topography

U.S. Geological Survey

Ground-water resources and water testing

State natural resources or environmental

departments

State water resources departments

County health departments

U.S. Geological Survey

National Water Well Association

Water-supply and septic-system construction

State health departments

State environmental or conservation departments

County extension agents

U.S. Environmental Protection Agency

U.S. Department of Agriculture

Land-use and zoning

State planning agencies

County planning and zoning agencies

This publication is one of a series of general interest publications prepared by the U.S. Geological Survey to provide information about the earth sciences, natural resources, and the environment. To obtain a catalog of additional titles in the series "General Interest

Publications of the U.S. Geological Survey," write:

Book and Open-File Reports Section

U.S. Geological Survey

Federal Center, Box 25425

Denver, CO 80225

Printed: 1988 


\section{Suggested Reading}

Baldwin, H.L., and McGuinness, C.L., 1963, A primer on ground water: U.S. Geological Survey, 26 p.

Cobb, E.L., and Morgan, M.E., 1978, Drinking water supplies in rural America: U.S. Environmental Protection Agency, National Demonstration Water Project, 164 p.

Craun, G.F., 1981, Outbreaks of water-borne disease in the United States, 1971-1978: Journal of American Water Works Association, vol. 73, no. 7, pp. 360-369.

Edward E. Johnson, Inc., 1966, Ground water and wells [1st ed.]: Saint Paul, Minn., 440 p.

Francis, J.D. (principal investigator), [1980], National statistical assessment of rural water conditions, Executive summary: Ithaca, N.Y., Cornell University, Department of Rural Sociology, U.S. Environmental Protection Agency, The Office of Drinking Water, $5 \mathbf{v}$.

Geyer, A.R., and McGlade, W.G., 1972, Environmental geology for land-use planning: Commonwealth of Pennsylvania Department of Environmental Resources, Environmental Geology Report 2, $37 \mathrm{p}$.

Gibb, J.P., 1973, Planning a domestic groundwater supply system: Illinois State Water Survey, Circular 116, 13 p.

Heath, R.C., 1983, Basic ground-water hydrology: U.S. Geological Survey Water-Supply Paper 2220, 84 p.

Keough, Carol, 1980, Water fit to drink: Emmaus, Pa., Rodale Press, 265 p.

Leopold, L.B., and Langbein, W.B., 1960, A primer on water: U.S. Geological Survey, $50 \mathrm{p}$.

Massachusetts Audubon Society, 1983, An introduction to groundwater and aquifers: Lincoln, Mass., Community Groundwater Protection Project, Groundwater Information Flyer no. 1, $12 \mathrm{p}$.

New York State Department of Health, 1966, Rural water supply: Albany, N.Y., 66 p.

Paulsen, Q.F., 1983, Guide to North Dakota's ground-water resources: U.S. Geological Survey Water-Supply Paper 2236, $25 \mathrm{p}$.

Peck, M.K., 1981, Troubleshooting water well failure: West Virginia Geological and Economic Survey Circular C-25, $18 \mathrm{p}$.

U.S. Bureau of Reclamation, 1977, Ground-water manual: Washington, D.C., U.S. Government Printing Office, $480 \mathrm{p}$.

U.S. Department of Agriculture, 1971, Water supply sources for the farmstead and rural home: Science and Education Administration Farmers Bulletin No. 2237, 18 p.

U.S. Environmental Protection Agency, 1974a, Manual of individual water-supply systems: EPA-430/9-74-007, 155 p. $1974 \mathrm{~b}$, Polluted groundwater-estimating the effects of man's activities: EPA-680/4-74-002, 99 p. 1980, Groundwater protection: Water Planning Division, Water Quality Management Report, 36 p.

U.S. National Science Foundation, 1983, Groundwater resources and contamination in the United States: U.S. Department of Commerce PB 84-126 358, Workshop Papers and Summary, $231 \mathrm{p}$. 
As the Nation's principal conservation agency, the Department of the Interior has responsibility for most of our nationally owned public lands and natural resources. This includes fostering the wisest use of our land and water resources, protecting our fish and wildlife, preserving the environmental and cultural values of our national parks and historical places, and providing for the enjoyment of life through outdoor recreation. The Department assesses our energy and mineral resources and works to assure that their development is in the best interests of all our people. The Department also has a major responsibility for American Indian reservation communities and for people who live in Island Territories under U.S.

Administration. 